\title{
Green building design
}

\author{
Xiao. Cheng ${ }^{1, a^{*}}$, Li. Jun. Dou ${ }^{2, b}$ \\ ${ }^{1}$ Changchun Institute of Technology, Changchun, Jilin, China \\ ${ }^{2}$ Changchun Institute of Technology, Changchun, Jilin, China \\ a958299242@qq.com, ${ }^{\mathrm{b}} 124109308 @ q q . c o m$
}

\begin{abstract}
Keywords: Concept; Evaluation System; Energy-Saving Technologies; Case Study.
Abstract: Green building design is different from the traditional architectural design, building not only for science, space utilization, architectural form, building structure to be considered, but from an environmental and energy point of view, the use of ecological, environmental science and energy disciplines technology, people, architecture and natural environmental development in the use of natural and artificial means to create good conditions, healthy living environment at the same time, as much as possible to control and reduce the impact on the natural environment and destruction, and fully reflects the nature of Request and balance between the returns. This paper discussed the concept of green building, green building assessment system, green building energy-saving technology and other aspects of the case.
\end{abstract}

\section{Green Building Concept}

\section{Definition Of Green Building}

The Green building refers to the entire life cycle of the building, the maximum conservation of resources (energy, land, water, materials), protecting the environment and reduce pollution, provide people with health, application and efficient use of space and the nature architectural harmony. "Green" and "green building" not only refers to the general sense, such as a roof garden or stereoscopic greening of specific measures, but also a concept or symbol, referring to the building to take advantage of natural environmental resources without damaging the environment the basic ecological balance. Green building is also known as ecological building, energy saving building, sustainable building, return to nature and construction.

\section{Three Elements Of Green Building}

Green buildings three elements are energy saving, environmental protection, applicable. Compared with traditional architecture, green building can better conserve energy and resources, reduce solid waste generation, and improve indoor air quality, improve building indoor comfort and lower operating costs in the construction and maintenance of the entire life cycle costs.

Green building have economic and environmental benefits and social benefits. For green building, based on the objective local conditions, local conditions to transport natural ventilation and natural lighting technology, using wind, solar and other renewable energy sources, effectively reducing the use of air-conditioning equipment and lighting equipment; general use better insulation performance envelope material, reduce indoor heat loss, which can reduce heating and cooling energy consumption. Compared with traditional architecture, the cost of green buildings than $2 \%$ economic building life cycle can be achieved within ten times the investment of even a few times. Meanwhile, the green building energy, water, materials, land and new energy use, building during operation to reduce the coal, electricity, natural gas and other resource consumption, thereby reducing the formation of greenhouse gas emissions and acid rain, to effectively reduce environmental pollution, has tremendous environmental benefits.

Green buildings improve air quality and comfort of the building interior, provide users with a healthy, comfortable, environmentally-friendly space, reduces room health problems occur, improving the quality of urban environment, it is possible to raise the environmental awareness of the whole society, changing people's environment philosophy, which can promote people, harmony between man and nature development has important social benefits. 


\section{Green Building And Climate}

Modern science and technology for the benefit of human life, machinery is used to adjust the air conditioning to improve our working environment. This way contrary to the climate has been widely applied in construction, it will generate a lot of economic and energy consumption, increasing environmental pollution, so that the occupants with the natural environment isolation. Green building design based on weather conditions and human comfort requirements, the rational organization of various architectural factors systematically building design.

Green building is a dynamic, developing new concept, its significance as technology and society will gradually enriched. Now, many countries have attached great importance to the development and research of green building, architectural design aspects have infiltrated the idea of green buildings, architects are trying to lead a "return to nature" of the building model.

\section{Out Of The Green Building Three Erroneous Zone}

\section{Green Cost Is Not The Same As A High Price}

In property sales in advertising campaign hype, "green building" is no exception of new words into their mouth, so that let people mistakenly believe that green building is a high-end grade atmosphere building.

How the cost of the green building, will become the factors that increase prices, housing and the ministry of construction Qiu Baoxing, a deputy minister accordingly answer:

Green building is a broad concept, green does not mean that the high cost price. Cave warm in winter and cool in summer, for example, make full use of its advantages to build a green building, the cost is not high also, good and inexpensive. Qiu said, we introduce the green building techniques and standards, give full consideration to these problems, the regulations adopted by the green building technology, equipment and products, and lower cost, less impact on the real estate price. Once put into use, will reduce the user's water, electricity and other resources.

\section{The Green Building Is Not The Same As The Modern, High-tech}

The green building and the development of building energy conservation way in high-end positioning, nobility, not going to happen; Actually the development path for Chinese, ordinary people, the green building can healthy development.

Qiu said, because there are some real estate developers in order to improve the housing prices and the misuse of the green building logo. Now we must vigorously promote green building logo, through to the building energy saving, water, land and materials in a specific measured, recorded data. Make the concept of green building from a simple quantitative testing standard, such false green will appear, people can tell, pseudo green exit the market in the end.

\section{The Green Building Is Not Only Limited To The New Building}

"New building energy efficiency work do well in our country, the basically follows the standard; but to transform a large number of existing buildings into the green building work is not very smooth, existing buildings is still a large energy consumption."

According to Qiu, existing buildings now from upstairs and downstairs is a pipeline heating, tandem, each household only consistent heat meter, this approach is not feasible. Now technical improvements, the introduction of European technology, mount a meter of each heat sink, low cost and good reconstruction method, changing the heating system is required.

\section{Three Green Building Energy Saving Technology}

\section{The Green Building Energy Saving Technical Measures}

\section{1) Reasonable Decorate Building Layout}

Green building energy saving is a combination of energy saving building design and equipment, at the beginning of construction design, which has laid a good foundation for energy-using equipment to reduce building energy consumption load has an important influence. When buildings after the confirmation of the surrounding environment, building energy efficiency mainly depends on 
building layout to reduce building energy consumption.

2) To Effectively Control The Indoor Environment

Daylight illumination through certain way to sunlight into indoor, through effective allocation, improve the indoor light feeling, bring comfort to the person, is widely used in the green buildings.

\section{Building Energy Efficiency Design Factor}

\section{1) The Shape Factor Building Energy Efficiency Design Factors}

Building shape coefficient refers to the area of the building is exposed to air and buildings surrounded by the ratio of area. The more complex shape, heat transfer area, the greater the energy consumption. But not shape coefficient, the smaller the better, need to have a best energy saving shape coefficient. Rectangular building coefficient with the height of the building, and is independent of the size, related to weather and building plane length-width ratio.

2) The Heat Transfer Coefficient Of Enclosure Structure

Retaining structure mainly have the effect of heat preservation and heat insulation, exterior wall play an important role, general use of lightweight and efficient heat preservation material. In cold regions, generally USES the solid brick rock wool sandwich composite wall, but usually could not reach the requirements of energy-saving heat preservation. Even in the same cold conditions, the thermal insulation layer is set in different places have different effect, therefore, suggest that thermal insulation layer set on the outside, can rise to prevent of condensed water from the wall.

\section{3) Windows And Doors Area Ratio}

In building construction, windows and doors insulation capability worst heat penetration doors generally accounted for about $50 \%$ of the total. Therefore, insulation weaknesses are windows and doors, but also the most energy-efficient focus needed.

\section{4) Building Location And Orientation}

Building heat obtained with different orientations and seasons of the building is different, when the small sun angle, the sun's rays will get a great room area. Therefore, the position and orientation of buildings and energy are closely related.

\section{Cases Of Green Building}

\section{Shanghai World Expo Venue}

a. Chinese Pavilion: Green landmarks

China Pavilion to consider energy conservation in terms of architectural form, energy efficient lighting systems. In terms of architectural form, and strive to building single building their own consumption reduction. For example, all the windows are double-glazed low energy use. Icemaking technology greatly reduce electricity load and improve the energy-saving systems.

China Pavilion rainwater collection system that can collect rainwater to irrigate plants and nature to clean roads and achieve rainwater utilization. Meanwhile in southern China Pavilion there is a wetland, around the building to absorb dust and other environmental pollution, to achieve the purpose of cleaning.

China Pavilion achieves energy saving in ventilation, solar energy. China Pavilion at the top of the exterior wall is by solar cells, the China Pavilion lighting provides a context.

b. World Axis: Let the sun poured into the ground

World axis using the "Yang Guan Valley" and sunken garden green building underground space . Six giant cone-shaped "Sun Valley" decibel distributed at the entrance and the central axis of the world, in favor of sunshine thrown in, improving air quality and reducing energy consumption.

World axes automatically adjust the indoor temperature through the ecosystem, so that people feel very comfortable. Ground source heat pump is a use of underground geothermal resources, heating and air conditioning system can be cooling, while near the Huangpu River, the introduction of the Huangpu River as a heat source, adjust the indoor environment.

Glass walls achieve the goal by the ring rainwater collection and recycling. The appearance of a 
good visual effects, in addition to the role of rainwater harvesting, rainwater is stored in the basement, through the filter can be used again to facilitate the greening irrigation.

\section{c. Theme Pavilion: Rookie Technology}

Use of solar roofing for energy generation. Theme pavilion roof solar panel area of 30,000 square meters, the annual generating capacity reached 2.5 million KW.h, use the grid pattern, will spread to the city grid solar power can reduce a lot of carbon dioxide emissions annually.

Theme Pavilion vertical planting greenery in the building, not only looks unique, but also for the construction put on the cloak of a layer of insulation. When summer comes, green wall form a good insulating wall, blocking the sun's radiation, reduce the indoor temperature. Winter, green plants absorb ultraviolet light, while blocking heat loss.

d. Expo Center: wisdom of green building

Expo Center Design aim is: green, energy saving and environmental protection. Through the energy, water, indoor air quality and many made from renewable resources control, making it a beautiful landscape.

Expo Center by using a variety of passive energy-saving technologies, maximizing energy-efficient buildings. Building Exterior features shading devices can reduce direct sunlight in summer, to protect the building, to create a good indoor environment.

Expo Center practice in all aspects of the design philosophy of environmental protection, all-steel, construction speed, low energy consumption, low pollution; selection of new energy saving materials supplies; architectural glass facades combine aluminum, ceramic plate and other forms of combination of different walls, look beautiful, sunny indoor meet people and fresh air requirements.

\section{American Academy Of California}

American Academy of California Golden Gate Park in San Francisco, built in 2008 changed Sciences, the world's most advanced scientific and cultural institutions. New buildings use energysaving, environmentally friendly building techniques for the sustainable development of urban construction, the establishment of a new standard. Green building techniques used are as follows:

\section{Improve Utilization, Lower Energy Consumption}

The building energy consumption by more than $30 \%$ of regulatory requirements, many solar cells embedded in the roof, will provide about 200,000 KW.h of renewable energy annually, vegetated roof to provide insulation for the top role in the building, thereby reducing air conditioning energy.

\section{Efficient Water-saving}

Roof planting a lot of green plants can effectively reduce the loss of rainwater, recycling rainwater, reducing the flushing toilet water waste. Aquarium of seawater from the Pacific, through the natural system to treat seawater will also be recycled.

\section{Natural Lighting And Ventilation}

The building using conventional techniques, including lighting and ventilation. Most of the buildings to use natural light, artificial lighting reduces energy consumption and reduce heat generation. Therefore, to ensure a minimum level of energy consumption.

Meanwhile, the use of renewable and recyclable building materials, the recycling of scrap waste, turning waste into treasure, fair use. 9000 tons of concrete blast was all for Richmond road construction, the base 120 tons of green waste also have been recovered.

\section{References:}

[1] Zhu, J. Green form: building energy efficiency design of space strategy research. Nanjing: southeast university, 2011.

[2] Wei, J.T. Green building in tai yuan, tai yuan university of technology, 2012.

[3] Hu, J.S. Residential design should be environmental, ecological and energy-saving consciousness. High and new technology enterprise in China, 7 (2014) 1-4.

[4] Wang, J. \& Xu, H.Y. Building energy consumption status and energy saving way. Journal of Chinese scientific and technological achievements, 19 (2012) 32-34. 
[5] Kang, L.W. Building energy efficiency design countermeasures. Journal of private science and technology, 5 (2011) 97-98.

[6]Sun, J.M. \& Zhang, Y.K. \& Sui, J.L. The green building evaluation system in domestic and foreign development present situation. Architectural technology, 1 (2014) 63-56. 